\title{
SISTEM PENDUKUNG KEPUTUSAN DISTRIBUSI BERAS MISKIN (RASKIN) MENGGUNAKAN LOGIKA SAMAR
}

\author{
Luther A. Latumakulita \\ Program Studi Matematika, FMIPA, Universitas Sam Ratulangi Manado, J1. Kampus Unsrat Bahu, \\ Malalayang, Manado, Sulawesi Utara, 95115, Indonesia \\ E-mail: lutherlatu@gmail.com
}

\begin{abstract}
Abstrak
Pada penelitian ini dilakukan rancang bangun sistem untuk membantu pihak pengambil keputusan dalam mendistribusikan beras miskin (RASKIN) bagi masyarakat miskin. Sistem ini dapat digunakan bagi pemerintah pada dinas sosial maupun pemerintah dalam tingkatan kelurahan.

Dengan menginput data keluarga dalam suatu kelurahan beserta dengan penghasilan perbulan maka sistem dapat menghitung derajat kemiskinan suatu keluarga berdasarkan fungsi keanggotaan fuzzy yang telah didefenisikan untuk kreteria penghasilan keluarga dan jumlah tanggungan keluarga. Dari derajat kemiskinan yang diperoleh maka dapat dipetakan kelayakan suatu keluarga dalam menerima bantuan beras miskin.

Ada beberapa tahap yang dilakukan untuk membuat sistem ini yaitu mendefenisikan fungsi keanggotaan fuzzy bagi setiap kriteria dalam hal ini kriteria dibagi dua yaitu kriteria jumlah penghasilan keluarga dan jumlah tanggungan keluarga, menetapkan bobot setiap kriteria, dan menetapkan range kategori kelayakan. Proses fusifikasi dilakukan terhadap data penghasilan keluarga dan jumlah tanggungan keluarga dan hasinya dikalikan dengan bobotnya masing-masing kemudian dijumlahkan untuk mendapat nilai total dan ditranformasikan ke prosentase kelayakan untuk menerima beras miskin.
\end{abstract}

Berdasarkan data-data keluarga yang dimasukan, sistem dapat mentukan kelayakan setiap keluarga dalam menerima beras miskin.

Kata Kunci: Beras Miskin, Fuzzy Logic, Sistem Penunjang Keputusan

\section{Pendahuluan}

Program beras miskin (Raskin) yang dimulai pada bulan Januari 2002 merupakan program lanjutan dari program Operasi Pasar Khusus (OPK) yang dirancang pemerintah dan dilaksanakan oleh Bulog pertengahan tahun 1998. Program ini adalah penyempurnaan dari program stabilitas harga beras, yang umumnya mahal dan juga kurang adil dinikmati semua orang terutama bagi masyarakat miskin.

Logika fuzzy sebagai salah satu komponen dari soft computing telah banyak diaplikasikan di berbagai bidang kehidupan. Salah satu aplikasi terpentingnya adalah untuk membantu manusia dalam melakukan pengambilan keputusan. Aplikasi logika fuzzy untuk pendukung keputusan ini akan diperlukan ketika semakin banyak kondisi yang menuntut adanya keputusan yang tidak hanya bisa dijawab dengan "ya" atau "tidak". Logika fuzzy dapat dterapkan dalam pengambilan keputusan pembagian Raskin agar lebih tepat sasaran dan mengurangi kecurangan dalam pembagian jatah Raskin

Rumusan masalah dalam penelitian ini adalah bagaimana mengembangakan suatu sistem penunjang keputusan yang dapat membantu dalam penyaluran beras miskin dengan menerapkan fuzzy logic dalam mengukur tingkat kemiskinan. Penelitian ini bertujuan untuk membuat suatu sistem pendukung keputusan yang dapat memberikan suatu alternatif keputusan bagi para pengambil keputusan dalam melakukan distribusi beras untuk keluarga miskin dengan menerapkan konsep logika fuzzy dalam mengukur tingkat kemiskinan keluarga penerima beras miskin berdasarkan criteria yang telah disebutkan dalam batasan masalah diatas

\section{Pengertian Raskin}

Program raskin (program penyaluran untuk keluarga miskin) adalah sebuah program dari pemerintah. Program tersebut adalah sebuah 
upaya untuk mengurangi beban penyaluran dari rumah tangga miskin sebagai bentuk dukungan dalam meningkatkan ketahanan pangan dengan memberikan perlindungan sosial beras murah dengan jumlah maksimal $15 \mathrm{~kg} /$ rumah tangga miskin/bulan dengan masing-masing seharga Rp. $1.600,00$ per $\mathrm{kg}$ (netto) di titik distribusi. Program ini mencakup di seluruh provinsi, sementara tanggung jawab dari distribusi beras dari gudang sampai ke titik distribusi di kelurahan di pegang oleh perum bulog.

Sasaran dari Program Raskin ini adalah meningkatkan aksen pangan kepada keluarga miskin untuk memenuhi kebutuhan pokok dalam rangka menguatkan ketahanan pangan rumah tangga dan mencegah penurunan konsumsi energi dan protein. Dalam memenuhi kebutuhan pangan tersebut, program Raskin perlu dilakasanakan agar masyarakat miskin benar-benar bisa merasakan manfaatnya, yakni dapat membeli beras berkualitas baik dengan harga terjangkau

\section{Logika Fuzzy, Himpunan Fuzzy dan Fungsi Keanggotan}

Logika fuzzy merupakan salah satu komponen pembentuk soft computing. Logika fuzzy pertama kali diperkenalakan oleh Prof.Lutfi A. Zaden pada tahun 1965. Dasar logika fuzzy adalah teori himpunan fuzzy. Pada teory himpunan fuzzy, peranan derajat keanggotaan sebagai penentu keberadaan elemen dalam suatu himpunan sangatlah penting. Nilai keanggotaan atau derajat keanggotaan menjadi ciri utama dari penalaran dengan logika fuzzy tersebut.

Ide dasar pada teori himpunan samar adalah setiap elemen dalam himpunan samar mempunyai derajat keanggotaan. Dengan demikian sebuah proposisi tidak hanya bernilai benar atau salah saja tetapi bisa bernilai sebagian benar atau sebagian salah. Nilai itu berupa bilangan real dalam interval $[0,1]$.

Logika fuzzy lahir berdasarkan fenomena fenomena alam yang serba tidak tepat dan samar ditinjau dari cara berpikir manusia, dimana pada kenyataannya tidak ada suatu kondisi atau pernyataan yang tepat $100 \%$ benar atau $100 \%$ salah. Prof. Lotfi A. Zadeh mengemukakan bahwa true atau false dalam logika Boolean tidak dapat merepresentasikan pernyataan yang tidak pasti yang berada diantara pernyataan true atau false tadi, seperti yang sering terjadi dalam dunia nyata. Untuk merepresentasikan nilai ketidakpastian antara true atau false tersebut, Prof. Lotfi A. Zadeh mengembangkan suatu teori berdasarkan conventional set yang disebutnya fuzzy set (himpunan fuzzy). Sebagai ganti dari pernyataan dengan nilai seluruhnya true atau semuanya false, logika fuzzy memberikan nilai yang spesifik pada setiap nilai diantara pernyataan true atau false dengan menentukan fungsi kenaggotaan (membership function) bagi tiap nilai input dari proses fuzzy (crisp input) dan derajat keanggotaan (degree of membership) yaitu menyatakan derajat dari crisp input sesuai membership function antara 0 sampai 1 , sehingga memungkinkan bagi suatu persamaan memiliki nilai true dan false secara bersamaan.

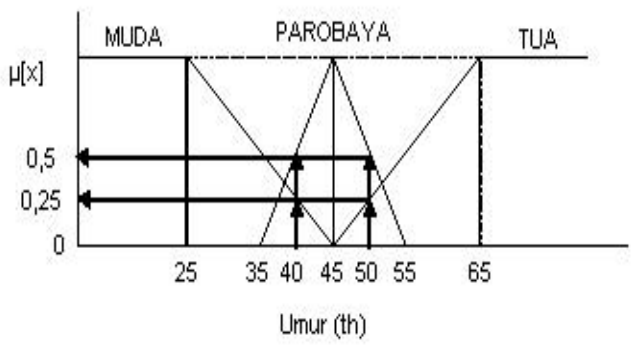

Gbr. 1 Contoh Himpunan Fuzzy

Dengan adanya himpunan fuzzy memungkinkan seseorang untuk dapat masuk kedalam 2 himpunan yang berbeda, MUDA dan PAROBAYA, PAROBAYA dan TUA, dan sebagainya. Seberapa besar eksistensinya dalam himpunan tersebut dapat dilihat pada nilai keanggotaannya. Dari Gbr.1 diatas, dapat dilihat bahwa :

- Seseorang yang berumur 40 tahun, termasuk dalam himpunan MUDA dengan $\mu$ MUDA[40] = 0,25; namun dia juga termasuk dalam himpunan PAROBAYA dengan $\mu$ PAROBAYA[40] $=0,5$. - Seseorang yang berumur 50 tahun, termasuk dalam himpunan MUDA dengan $\mu$ MUDA[50] = 0,25; namun dia juga termasuk dalam himpunan PAROBAYA dengan $\mu$ PAROBAYA[50] $=0,5$.

Keanggotaan fuzzy memberikan suatu ukuran terhadap pendapat atau keputusan, sedangkan probabilitas mengindikasikan proporsi terhadap keseringan suatu hasil bernilai benar dalam jangka panjang. Misalnya, jika nilai keanggotaan suatu himpunan fuzzy MUDA adalah 0,9 maka tidak perlu dipermasalahkan berapa seringnya nilai itu diulang secara individual untuk mengharapkan suatu hasil yang hampir pasti muda. Di lain pihak, nilai probabilitas 0,9 muda berarti $10 \%$ dari himpunan tersebut diharapkan tidak muda.

Fungsi keanggotaan (membership function) adalah suatu kurva yang menunjukan pemetaan titik - titik input data kedalam nilai keanggotaanya (sering juga disebut dengan derajat keanggotaan) yang memiliki interval antara 0 sampai 1 (Kusumadewei, 2004 : p8). Salah satu cara yang dapat digunakan untuk mendapatkan 
nilai keanggotaan adalah dengan melalui pendekatan fungsi. Ada beberapa fungsi yang bisa digunakan.

\section{Pengertian dan Tujuan Sistem Pendukung Keputusan}

Turban, Aronson dan Liang (2005) menunjukkan sistem pendukung keputusan (SPK) sebagai sebuah sistem yang dimaksudkan untuk mendukung para pengambil keputusan manajerial dalam situasi keputusan semiterstruktur. Sistem pendukung keputusan dimaksudkan untuk menjadi alat bantu bagi para pengambil keputusan untuk memperluas kapabilitas mereka, namun tidak untuk menggantikan penilaian mereka. Tujuan Sistem Pendukung Keputusan: a) Membantu manejer membuat keputusan untuk memecahkan masalah semiterstruktur; b) Mendukung penilaian manajer, bukan mencoba menggantikannya; c) Meningkatkan efektifitas pengambilan keputusan manajer daripada efisiensinya.

\section{Perancangan Sistem}

Perancangan sistem diawali dengan membuat struktur tabel dan relasi antar tabel. Struktur Tabel dapat dilihat pada Tabel 1, sedangkan untuk Relasi Antar Tabel dapat dilihat pada Gbr. 2.

TABEL 1

Struktur Tabel Keluarga

\begin{tabular}{l|l|l}
\hline \multicolumn{1}{c|}{ Field } & \multicolumn{1}{|c}{ Tipe } & \multicolumn{1}{|c}{ Ket } \\
\hline ID & Integer (10) & Primary key \\
\hline Nama Keluarga & Varchar (255) & \\
\hline ID Lingkungan & Integer (10) & $\begin{array}{l}\text { Foreign Key (Reference } \\
\text { dari field ID pada table } \\
\text { lingkungan) }\end{array}$ \\
\hline N_Penghasilan & Double $(15,5)$ & \\
\hline N_Anggota & Double $(15,5)$ & \\
\hline N_Total & Double $(15,5)$ & \\
\hline Penghasilan & Integer $(10)$ & \\
\hline
\end{tabular}

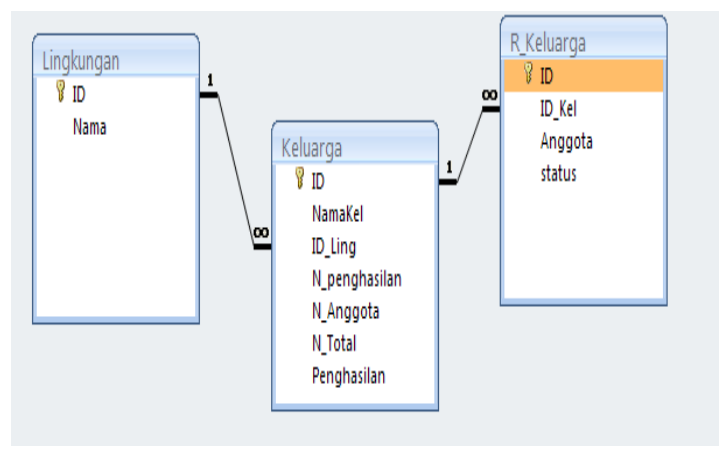

Gbr. 2 Relasi Antar Tabel
Relasi yang terjadi atara table lingkungan dan keluarga yaitu relasi One to Many dengan sisi many adalah table Lingkungan pada field ID dan sisi One adalah table keluarga pada field ID_Keluarga. Dilain pihak tabe; keluarga berelasi dengan table R_Keluarga juga menganut jenis relaswi One to Many denga sisi many adalah table keuarga pada field ID dan sisi one adalah table R_Keluarga pada field ID_Kel.

\section{Hasil dan Pembahasan}

Hasil Penelitian ini dapat dilihat dalam program aplikasi yang dibangun selanjutnya akan dibahas setiap antar muka yang dalam penulisan ini menggunakan istilah form seperti berikut

Form menu utama adalah form yang pertama dimunculkan pada saat program dijalankan, namun menu-menu yang tersedia masih dalam keadaan tidak aktif sampai kepada tahapan login dilakukan barulah menu-menu yang tersdia diaktifkan kembali sesuai dengan hak pemakai yang telah diatur. Form Menu Utama dapat dilihat pada Gbr. 3 dibawah ini:

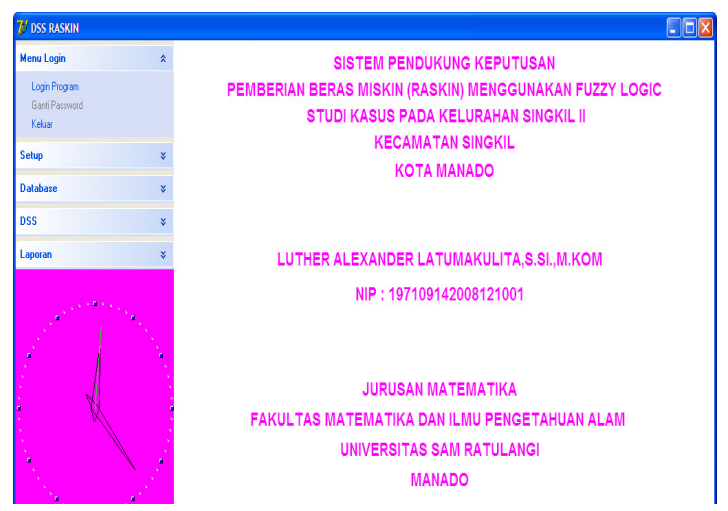

Gbr. 3 Form Menu Utama

Selain Form Menu Utama, juga terdapat Form Login, Form Ganti Password, Form Setup Fungsi Penghasilan (Lihat Gbr. 4), Form Setup Fungsi Anggota Tanggungan, Form Pembobotan Kriteria, Form Penginputan Data Lingkungan, Form Penginputan Data Keluarga, Form Penentuan Keputusan, serta Contoh Laporan Hasil Keputusan (Gbr. 5). Untuk kepentingan penulisan paper ini, maka tampilan form akan dibatasi. 


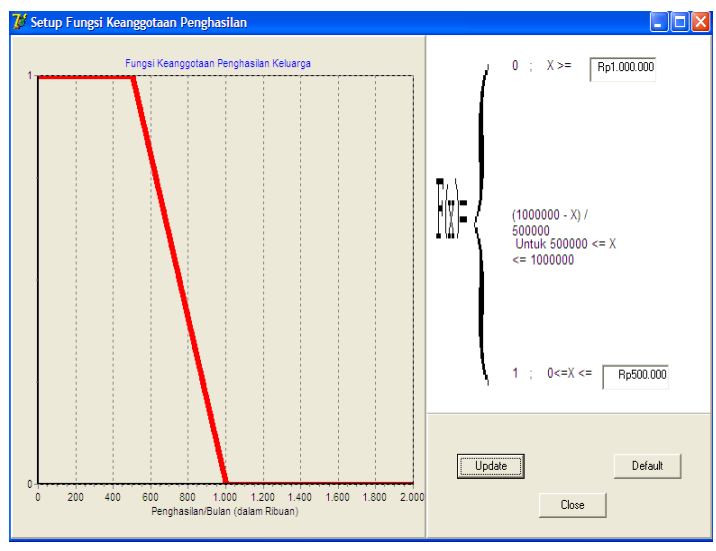

Gbr. 4 Form Setup Fungsi Penghasilan

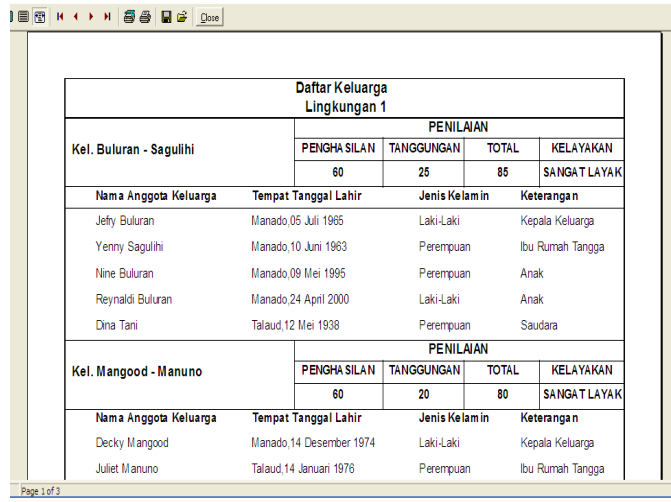

Gbr. 5 Contoh Laporan

\section{Kesimpulan dan Saran}

Sistem Pendukung Keputusan Pemberian Beras Miskin (RASKIN) Menggunakan Fuzzy Logic dapat membantu pengambil keputusan dalam mengambil keputusan berkaitan dengan distribusi beras miskin. Penggunakan Fuzzy Logic dalam system ini menghasilkan hasil perhitungan kelayakan penerimaan setiap keluarga di Kelurahan Singkil II menjadi lebih logis dan dapat diterima kebenarannya

Sistem ini dapat dikembangkan sengga mencakup system informasi kependudukan secara menyeluruh dengan tetap menyertakan peruses pendukung keputusan yang telah dibangun ini. Diharapkan agar system ini dapat diterapkan sehingga dapat mambantu penyaluran beras miskin dan tepat sasaran.

\section{Referensi}

[1] Fathansyah. 1999. Basis Data. Bandung: Informatika

[2] Hermawan Julius, 2005, "Membangun Decision Support System”, Penerbit Andi, Yogyakarta

[3] Kadir, Abdul. 2002. Pengenalan Sistem Informasi. Yogyakarta: Andi

[4] Kawengian, R. 2008. Sistem Informasi Perpustakaan Propinsi Sulawesi Utara. [skripsi]. FMIPA UNSRAT, Manado.

[5] Kusumadewi, Sri. 2010. Aplikasi Logika Fuzzy untuk Pendukung Keputusan. Yogyakarta: Graha Ilmu

[6] Wang, Shin-Yun, and Chih-Chiang Hwang. 2011. An application of fuzzy set theory to the weighted average cost of capital and capital structure decision Technology and Investment 1.4 (2010): 248+.

[7] http://id.wikipedia.org/wiki/Sistem_pendukun g_keputusan

[8] http://typecat.com/pdf/PENGERTIANRASKIN.html 